\title{
ANALISIS TINGKAT KEPUASAN NASABAH TERHADAP WEBSITE PEGADAIAN MENGGUNAKAN METODE TAM
}

\author{
Topan Rahmanto ${ }^{1}$, Nia Nuraeni ${ }^{2}$ \\ 1,2 Universitas Nusa Mandiri \\ e-mail: ${ }^{1}$ topan.rahmannto.tr@gmail.com, ${ }^{2}$ nia.nne@nusamandiri.ac.id
}

\begin{abstract}
Abstrak
Penelitian ini bertujuan untuk mengetahui dan menganalisis pengaruh perceived usefulness dan perceived ease of use terhadap behavioral intention to use dalam penerapan tingkat kepuasan nasabah di PT. Pegadaian (Persero). Penelitian ini berjenis kuantitatif deskriptif dengan sumber data menggunakan data primer. Sampel yang digunakan dalam penelitian ini sebanyak 30 orang nasabah di PT. Pegadaian (Persero) Dengan alat analisis yang dipakai menggunakan SPSS ver. 24. Hasil penelitian ini menunjukan bahwa secara parsial perceived usefulness tidak berpengaruh dan tidak signifikan terhadap behavioral intention to use dan perceived ease of use berpengaruh dan signifikan terhadap behavioral intention to use. Sedangkan secara parsial perceived usefulness dan perceived ease of use berpengaruh dan signifikan terhadap behavioral intention to use dengan tingkat koefisien determinasi sebesar $86,4 \%$ sedangkan sisanya $13,6 \%$ dijelaskan oleh variabel-variabel lain yang tidak diteliti dalam penelitian ini.
\end{abstract}

Kata Kunci: Technology Acceptance Model (TAM), dan Kepuasan Nasabah

\begin{abstract}
This study aims to determine and analyze the effect of perceived usefulness and perceived ease of use on behavioral intention to use in the application of customer satisfaction levels at PT. Pegadaian (Persero). This research is a descriptive quantitative type with data sources using primary data. The sample used in this study were 30 customers at PT. Pegadaian (Persero) With the analytical tool used using SPSS ver. 24. The results of this study indicate that partially perceived usefulness has no effect and is not significant on behavioral intention to use and perceived ease of use has an effect and is significant on behavioral intention to use. While partially perceived usefulness and perceived ease of use have a significant and significant effect on behavioral intention to use with a coefficient of determination of $86.4 \%$ while the remaining $13.6 \%$ is explained by other variables not examined in this study.
\end{abstract}

Keywords: Technology Acceptance Model (TAM), customer satisfaction

\section{Pendahuluan}

Perkembangan teknologi Informasi merupakan unsur pokok yang secara implisit melekat dalam konsep pembangunan yang terencana. Kegiatan pembangunan manapun juga dapat berlangsung dan mencapai sasaran bila dalam setiap tahapan perencanaan, pelaksanaan, dan pengawasan informasi yang memadai. Informasi memang diperoleh melalui kegiatan komunikasi tetapi yang sesungguhnya yang menentukan nilai komunikasi adalah informasi yang dibawanya. (Ahmad, 2013).
Dengan pesatnya perkembangan teknologi saat ini juga berpengaruh terhadap model pengembangan sebuah aplikasi dalam memprediksi suatu aktivitas masyarakatnya. TAM dapat digunakan untuk memprediksi adopsi penggunaan aplikasi IT dalam suatu organisasi. (Wulandari, 2020).

The Concept of Technology Acceptance Model (TAM), merupakan teori yang menawarkan landasan untuk mempelajari dan memahami perilaku pengguna teknologi dalam menerima dan menggunakan teknologi yang ditawarkan. Model TAM dikembangkan dari teori 
psikologis, yang menjelaskan perilaku pengguna teknologi berdasarkan keyakinan, sikap, niat, dan hubungan perilaku pengguna. (Atchariyachanvanich et al., 2011)

Jahangir dan Begum yang mengadaptasi TAM untuk mempelajari sikap penerimaan internet banking di Bangladesh. Hasil penelitian menunjukan bahwa perceived usefulness dan perceived ease of use, berpengaruh terhadap behavioral intention to use.(Jahangir \& Begum, 2008)

Hartatik dan Budihartanti yang mengadaptasi TAM untuk mempelajari sikap penerimaan aplikasi Go-jek di Jakarta. Hasil penelitian menunjukkan bahwa terdapat pengaruh yang positif dan signifikan antara variabel perceived usefulness, dan perceived ease of use terhadap variabel behavioral intention to use dalam penerapan tingkat kepuasan pelanggan terhadap aplikasi Go-jek di Jakarta dengan nilai korelasi sebesar 36,54 persen. (Hartatik \& Budihartanti, 2020)

Tujuan dari penelitian ini yaitu untuk menilai kepuasan nasabah terhadap website Pegadaian.

\section{Metode Penelitian}

Ada banyak metode serta model dalam sistem pendukung keputusan tetapi dalam penelitian ini digunakan metode Technology Acceptance Model atau sering disingkat dengan metode TAM. Dalam penelitian ini tiga tahap penelitian yang dilakukan dengan cara:

a. Observasi

Observasi atau pengamatan pengumpulan data yang cukup efektif untuk mempelajari suatu sistem. Pada waktu melakukan observasi, dalam penelitian ini pengumpulan data dengan cara memberi kuesioner kepada nasabah yang pernah menggunakan website PT. Pegadaian (Persero).

b. Wawancara

Penulis memperoleh data-data serta meneliti kebenaran informasi dan datadata tersebut dengan melakukan tanya jawab secara langsung dengan nasabah dari kalangan masyarakat dengan profesi yang berbeda dan tingkat usia yang juga berbeda. Wawancara merupakan pertemuan yang dilakukan oleh dua orang dengan tujuan bertukar informasi maupun ide dengan cara bertanya dan menjawab sehingga dihasilkan sebuah kesimpulan dalam topik tertentu(Sugiyono, 2015)

c. Studi Pustaka

Melakukan studi kepustakaan untuk pengumpulan data dan informasi yang diperoleh dari perpustakaan, jurnaljurnal, artikel dan internet yang berkaitan dengan penelitian ini.

\section{Hasil dan Pembahasan}

Dalam penelitian ini, objek penelitian yang digunakan adalah pegadaian. Pegadaian adalah kegiatan menjamin barang-barang berharga untuk memperoleh uang dan barang yang dijaminkan akan di tebus kembali oleh nasabahnya sesuai perjanjian (Kasmir, 2015).

Secara umum tahap-tahap yang dilakukan dalam penelitian ini meliputi tahap sebagai berikut:

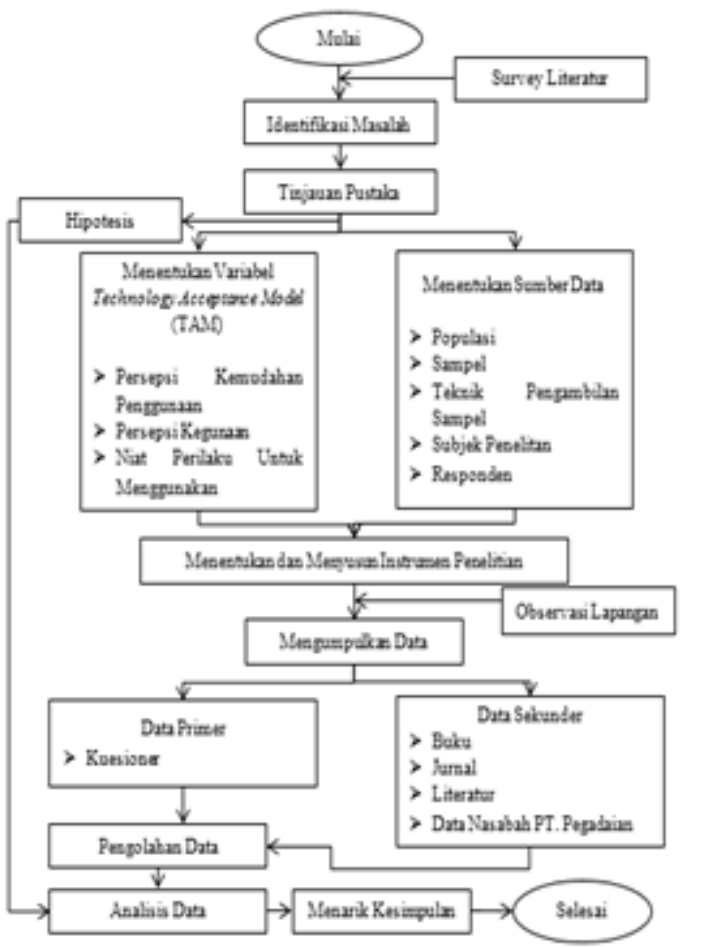

Gambar 1 Diagram Alur Tahapan Penelitian

oleh Pengisian kuesioner yang dilakukan menggunakan skala likert dengan ukuran interval. Skala likert digunakan untuk mengukur sikap, pendapat dan persepsi seseorang atau sekelompok orang tentang fenomena sosial (Sugiyono, 2014). Skala likert yang digunakan pada penelitian ini 
menggunakan skala lima dengan kategori, yaitu: skor 1 untuk jawaban sangat tidak puas, skor 2 untuk jawaban tidak puas, skor 3 untuk jawaban netral, skor 4 untuk jawaban puas, dan skor 5 untuk jawaban sangat puas.

Tabel 1 Kategori Skala

\begin{tabular}{ll}
\hline Pernyataan & Skor \\
\hline Sangat Puas (SP) & 5 \\
Puas (P) & 4 \\
Netral (N) & 3 \\
Tidak Puas (TP) & 2 \\
Sangat Tidak Puas (STP) & 1 \\
\hline
\end{tabular}

Data yang diperoleh dari 30 orang nasabah, responden yang berdasarkan jenis kelamin:

Tabel 2. Responden Berdasarkan Jenis Kelamin

\begin{tabular}{|c|c|c|c|c|c|}
\hline & & $\begin{array}{c}\text { Freque } \\
\text { ncy }\end{array}$ & $\begin{array}{c}\text { Perc } \\
\text { ent }\end{array}$ & $\begin{array}{c}\text { Vali } \\
\text { d } \\
\text { Perc } \\
\text { ent }\end{array}$ & $\begin{array}{c}\text { Cumula } \\
\text { tive } \\
\text { Percent }\end{array}$ \\
\hline \multirow[t]{3}{*}{$\begin{array}{l}\text { Val } \\
\text { id }\end{array}$} & $\begin{array}{l}\text { Laki- } \\
\text { Laki }\end{array}$ & 17 & 56,7 & 56,7 & 56,7 \\
\hline & $\begin{array}{l}\text { Peremp } \\
\text { uan }\end{array}$ & 13 & 43,3 & 43,3 & 100,0 \\
\hline & Total & 30 & 100,0 & 100,0 & \\
\hline
\end{tabular}

Berdasarkan tabel diatas menunjukan bahwa responden berjenis kelamin laki-laki sebanyak 17 responden atau sebesar $56,7 \%$ sedangkan perempuan sebanyak 13 responden atau sebesar $43,3 \%$. Hal ini menunjukan bahwa sebagian besar responden dalam penelitian ini berjenis kelamin laki-laki.

Data yang diperoleh dari 30 orang nasabah, responden yang berdasarkan usia.
Tabel 3 Responden Berdasarkan Usia

\begin{tabular}{|c|c|c|c|c|c|}
\hline & & $\begin{array}{c}\text { Freque } \\
\text { ncy }\end{array}$ & $\begin{array}{c}\text { Perce } \\
\text { nt }\end{array}$ & $\begin{array}{c}\text { Valid } \\
\text { Perce } \\
\text { nt } \\
\end{array}$ & $\begin{array}{c}\text { Cumulat } \\
\text { ive } \\
\text { Percent } \\
\end{array}$ \\
\hline \multirow{16}{*}{$\begin{array}{l}\text { Val } \\
\text { id }\end{array}$} & $<30$ & 8 & 26,7 & 26,7 & 26,7 \\
\hline & Tah & & & & \\
\hline & un & & & & \\
\hline & $31-$ & 10 & 33,3 & 33,3 & 60,0 \\
\hline & 40 & & & & \\
\hline & Tah & & & & \\
\hline & un & & & & \\
\hline & 41- & 9 & 30,0 & 30,0 & 90,0 \\
\hline & 50 & & & & \\
\hline & Tah & & & & \\
\hline & un & & & & \\
\hline & $>50$ & 3 & 10,0 & 10,0 & 100,0 \\
\hline & Tah & & & & \\
\hline & un & & & & \\
\hline & Tota & 30 & 100,0 & 100,0 & \\
\hline & 1 & & & & \\
\hline
\end{tabular}

Berdasarkan tabel diatas menunjukan bahwa responden yang berusia 31-40 Tahun sebanyak 10 responden atau sebesar 33,3\%, usia 41-50 Tahun sebanyak 9 responden atau sebesar $30 \%$, usia $<30$ Tahun sebanyak 8 responden atau sebesar $26,7 \%$, dan usia $>50$ Tahun sebanyak 3 responden atau sebesar $10 \%$. Hal ini menunjukan bahwa sebagian besar responden dalam penelitian ini berusia 3140 Tahun.

Data yang diperoleh dari 30 orang nasabah, $r$ esponden yang berdasarkan pendidikan terakhir.

Tabel 4 Responden Berdasarkan

Pendidikan

\begin{tabular}{|c|c|c|c|c|c|}
\hline & & $\begin{array}{c}\text { Frequen } \\
\text { cy }\end{array}$ & $\begin{array}{c}\text { Perce } \\
\text { nt }\end{array}$ & $\begin{array}{c}\text { Valid } \\
\text { Perce } \\
\text { nt }\end{array}$ & $\begin{array}{c}\text { Cumulati } \\
\text { ve } \\
\text { Percent }\end{array}$ \\
\hline $\begin{array}{l}\text { Vali } \\
\text { d }\end{array}$ & $\begin{array}{l}\text { SLTA/SM } \\
\text { A }\end{array}$ & 14 & 46,7 & 46,7 & 46,7 \\
\hline & $\begin{array}{l}\text { Diploma } \\
\text { (D3) }\end{array}$ & 10 & 33,3 & 33,3 & 80,0 \\
\hline
\end{tabular}




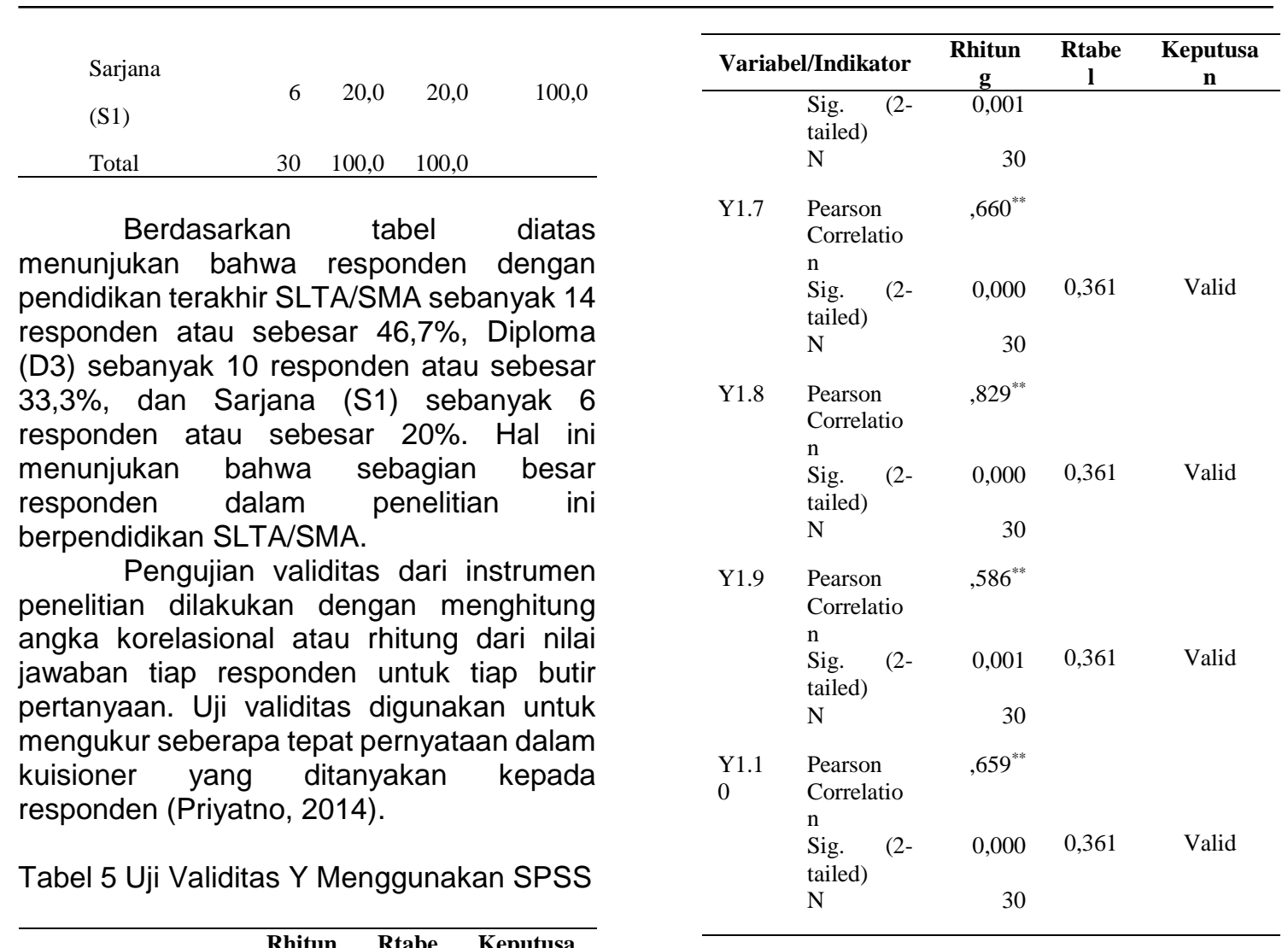






\begin{tabular}{|c|c|c|c|c|}
\hline \multicolumn{2}{|c|}{$\begin{array}{c}\text { Variabel/Indikat } \\
\text { or }\end{array}$} & \multirow{2}{*}{$\begin{array}{c}\text { Rhitun } \\
\mathbf{g} \\
, 768^{* *}\end{array}$} & \multirow[t]{2}{*}{$\begin{array}{c}\text { Rtab } \\
\text { el }\end{array}$} & \multirow[t]{2}{*}{$\begin{array}{c}\text { Keputus } \\
\text { an }\end{array}$} \\
\hline \multirow[t]{3}{*}{$\mathrm{X} 1.4$} & Pearson & & & \\
\hline & $\begin{array}{l}\text { Correlati } \\
\text { on } \\
\text { Sig. (2- } \\
\text { tailed) }\end{array}$ & 0,000 & \multirow[t]{2}{*}{0,361} & \multirow[t]{2}{*}{ Valid } \\
\hline & $\mathrm{N}$ & 30 & & \\
\hline \multirow[t]{3}{*}{$\mathrm{X} 1.5$} & Pearson &, $739^{* * *}$ & \multirow{3}{*}{0,361} & \multirow{3}{*}{ Valid } \\
\hline & $\begin{array}{l}\text { Correlati } \\
\text { on } \\
\text { Sig. (2- } \\
\text { tailed) }\end{array}$ & 0,000 & & \\
\hline & $\mathrm{N}$ & 30 & & \\
\hline \multirow[t]{4}{*}{ X1.6 } & Pearson &, $536^{* * *}$ & \multirow{4}{*}{0,361} & \multirow{4}{*}{ Valid } \\
\hline & $\begin{array}{l}\text { Correlati } \\
\text { on }\end{array}$ & & & \\
\hline & $\begin{array}{l}\text { Sig. } \\
\text { tailed) }\end{array}$ & 0,002 & & \\
\hline & $\mathrm{N}$ & 30 & & \\
\hline \multirow[t]{4}{*}{$\mathrm{X} 1.7$} & Pearson &, $792^{* *}$ & \multirow{4}{*}{0,361} & \multirow{4}{*}{ Valid } \\
\hline & $\begin{array}{l}\text { Correlati } \\
\text { on }\end{array}$ & & & \\
\hline & $\begin{array}{l}\text { Sig. } \\
\text { tailed) }\end{array}$ & 0,000 & & \\
\hline & $\mathrm{N}$ & 30 & & \\
\hline \multirow[t]{4}{*}{$\mathrm{X} 1.8$} & Pearson &, $731^{* *}$ & \multirow{4}{*}{0,361} & \multirow{4}{*}{ Valid } \\
\hline & $\begin{array}{l}\text { Correlati } \\
\text { on }\end{array}$ & & & \\
\hline & $\begin{array}{l}\text { Sig. (2- } \\
\text { tailed) }\end{array}$ & 0,000 & & \\
\hline & $\mathrm{N}$ & 30 & & \\
\hline \multirow[t]{4}{*}{ X1.9 } & Pearson &, $672^{* * *}$ & \multirow{4}{*}{0,361} & \multirow{4}{*}{ Valid } \\
\hline & $\begin{array}{l}\text { Correlati } \\
\text { on }\end{array}$ & & & \\
\hline & $\begin{array}{l}\text { Sig. (2- } \\
\text { tailed) }\end{array}$ & 0,000 & & \\
\hline & $\mathrm{N}$ & 30 & & \\
\hline \multirow{4}{*}{$\begin{array}{l}\text { X1.1 } \\
0\end{array}$} & Pearson & $694^{* * *}$ & \multirow{4}{*}{0,361} & \multirow{4}{*}{ Valid } \\
\hline & $\begin{array}{l}\text { Correlati } \\
\text { on }\end{array}$ & & & \\
\hline & $\begin{array}{l}\text { Sig. (2- } \\
\text { tailed) }\end{array}$ & 0,000 & & \\
\hline & $\mathrm{N}$ & 30 & & \\
\hline
\end{tabular}

Berdasarkan hasil perhitungan yang telah dilakukan pada tabel 6 menunjukan bahwa masing-masing indikator pada variabel Perceived Usefulness (X1) menunjukkan hasil yang valid, karena syarat minimum lebih besar dari 0,361 atau telah terpenuhi, sehingga dapat melakukan pengujian validitas pada variabel selanjutnya. Perceived Usefulness dapat diartikan sebagai persepsi seseorang tentang apakah menggunakan suatu teknologi baru dapat membantu meningkatkan kinerjanya atau tidak. Liao dan Cheung dalam (Subagio \& Jessica, 2020).

Tabel 7 Uji Validitas X2 Menggunakan SPSS

\begin{tabular}{|c|c|c|c|c|}
\hline \multicolumn{2}{|c|}{ Variabel/Indikator } & $\begin{array}{c}\text { Rhitun } \\
\text { g }\end{array}$ & $\begin{array}{c}\text { Rtabe } \\
\text { I }\end{array}$ & Keputusa \\
\hline $\mathrm{X} 2.1$ & $\begin{array}{l}\text { Pearson } \\
\text { Correlatio } \\
\mathrm{n} \\
\text { Sig. } \\
\text { tailed) } \\
\mathrm{N}\end{array}$ & $\begin{array}{r}0,000 \\
30\end{array}$ & 0,361 & Valid \\
\hline $\mathrm{X} 2.2$ & $\begin{array}{l}\text { Pearson } \\
\text { Correlatio } \\
\mathrm{n} \\
\text { Sig. (2- } \\
\text { tailed) } \\
\mathrm{N}\end{array}$ & $\begin{array}{r}0,000 \\
30\end{array}$ & 0,361 & Valid \\
\hline $\mathrm{X} 2.3$ & $\begin{array}{l}\text { Pearson } \\
\text { Correlatio } \\
\mathrm{n} \\
\text { Sig. (2- } \\
\text { tailed) } \\
\mathrm{N}\end{array}$ & $\begin{array}{r}0,002 \\
30\end{array}$ & 0,361 & Valid \\
\hline $\mathrm{X} 2.4$ & $\begin{array}{l}\text { Pearson } \\
\text { Correlatio } \\
\mathrm{n} \\
\text { Sig. (2- } \\
\text { tailed) } \\
\mathrm{N}\end{array}$ & $\begin{array}{r}0,000 \\
30\end{array}$ & 0,361 & Valid \\
\hline $\mathrm{X} 2.5$ & $\begin{array}{l}\text { Pearson } \\
\text { Correlatio } \\
\mathrm{n} \\
\text { Sig. } \\
\text { tailed }) \\
\mathrm{N}\end{array}$ & $\begin{array}{r}0,001 \\
30\end{array}$ & 0,361 & Valid \\
\hline $\mathrm{X} 2.6$ & $\begin{array}{l}\text { Pearson } \\
\text { Correlatio } \\
\mathrm{n} \\
\text { Sig. (2- } \\
\text { tailed) } \\
\mathrm{N}\end{array}$ & $\begin{array}{r}0,002 \\
30\end{array}$ & 0,361 & Valid \\
\hline $\mathrm{X} 2.7$ & $\begin{array}{l}\text { Pearson } \\
\text { Correlatio } \\
\mathrm{n} \\
\text { Sig. (2- } \\
\text { tailed) } \\
\mathrm{N}\end{array}$ & $\begin{array}{r}0,000 \\
30\end{array}$ & 0,361 & Valid \\
\hline $\mathrm{X} 2.8$ & $\begin{array}{l}\text { Pearson } \\
\text { Correlatio } \\
\mathrm{n} \\
\text { Sig. } \\
\text { tailed }) \\
\mathrm{N}\end{array}$ & $\begin{array}{r}0,000 \\
30\end{array}$ & 0,361 & Valid \\
\hline X2.9 & $\begin{array}{l}\text { Pearson } \\
\text { Correlatio } \\
\mathrm{n} \\
\text { Sig. (2- } \\
\text { tailed) } \\
\mathrm{N}\end{array}$ & $\begin{array}{r}0,000 \\
30\end{array}$ & 0,361 & Valid \\
\hline $\begin{array}{l}\mathrm{X} 2.1 \\
0\end{array}$ & $\begin{array}{l}\text { Pearson } \\
\text { Correlatio }\end{array}$ &, $655^{* *}$ & 0,361 & Valid \\
\hline
\end{tabular}




\begin{tabular}{|c|c|c|c|}
\hline Variabel/Indikator & $\begin{array}{c}\text { Rhitun } \\
\text { g }\end{array}$ & $\begin{array}{c}\text { Rtabe } \\
1\end{array}$ & $\begin{array}{c}\text { Keputusa } \\
\text { n }\end{array}$ \\
\hline $\begin{array}{l}\text { Sig. } \\
\text { tailed })\end{array}$ & 0,000 & & \\
\hline $\mathrm{N}$ & 30 & & \\
\hline
\end{tabular}

Berdasarkan hasil perhitungan yang telah dilakukan pada tabel 7 menunjukan bahwa masing-masing indikator pada variabel Perceived Ease of Use (X2) menunjukkan hasil yang valid, karena syarat minimum lebih besar dari 0,361 atau telah terpenuhi, sehingga dapat melakukan pengujian selanjutnya.

Uji reliabilitas merupakan alat untuk mengukur suatu kuesioner ayng merupakan indikator dari variabel. Suatu variabel dikatan reliabel atau handal jika jawaban seseorang terhadap pernyataan adalah konsisten atau stabil dari waktu ke waktu (Ghozali \& Ratmono, 2017). Pengujian reliabilitas dalam penelitian ini untuk menunjukan tingkat reliabilitas konsistensi internal teknik yang digunakan adalah dengan mengukur koefisien Cronbach's Alpha dengan bantuan program SPSS 24 . Nilai alpha bervariasi dari $0-1$, suatu pertanyaan dapat dikategorikan reliabel jika nilai alpha lebih besar dari 0,6 :

Tabel 8 Uji Validitas Y Reliability Statistics

\begin{tabular}{cc}
\hline $\begin{array}{c}\text { Cronbach's } \\
\text { Alpha }\end{array}$ & N of Items \\
\hline 0,870 & 10 \\
\hline
\end{tabular}

Berdasarkan tabel di atas terlihat bahwa variabel Behavioral Intention to Use mempunyai nilai Cronbach's Alpha sebesar 0,870 dari 10 pertanyaan, karena memiliki nilai Cronbach's Alpha lebih besar dari 0,6. Maka dinyatakan bahwa variabel Behavioral Intention to Use memiliki data yang reliabel.

Tabel 9 Uji Validitas X1 Reliability Statistics

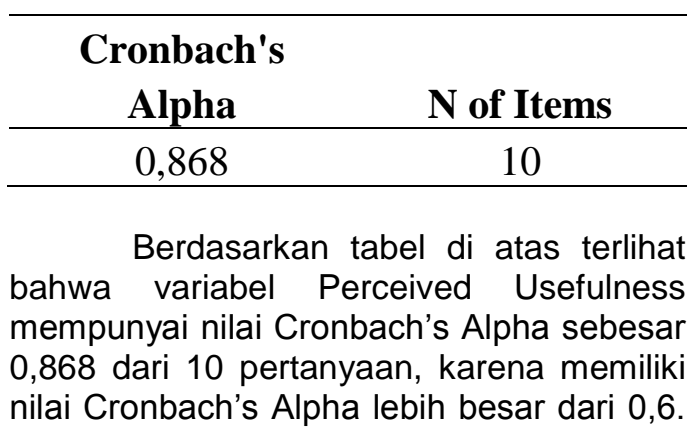

Maka dinyatakan bahwa variabel Perceived Usefulness memiliki data yang reliabel.

Tabel 10 Uji Validitas X2 Reliability Statistics

\begin{tabular}{cc}
\hline $\begin{array}{c}\text { Cronbach's } \\
\text { Alpha }\end{array}$ & N of Items \\
\hline 0,869 & 10 \\
\hline
\end{tabular}

Berdasarkan table di atas terlihat bahwa variabel Perceived Ease of Use mempunyai nilai Cronbach's Alpha sebesar 0,869 dari 9 pertanyaan, karena memiliki nilai Cronbach's Alpha lebih besar dari 0,6. Maka dinyatakan bahwa variabel Perceived Ease of Use memiliki data yang reliabel.

Analisis statistik deskriptif adalah analisis yang menjelaskan bagaimana data dikumpulkan dan diringkas pada hal-hal yang penting dari data tersebut.(Sholikhah, 2016).

Tabel 11 Hasil Uji Statistik Deskriptif

\begin{tabular}{|c|c|c|c|c|c|}
\hline & $\mathbf{N}$ & $\begin{array}{c}\text { Minimu } \\
\text { m }\end{array}$ & $\begin{array}{c}\text { Maximu } \\
\text { m }\end{array}$ & $\begin{array}{c}\text { Mea } \\
\mathbf{n}\end{array}$ & $\begin{array}{c}\text { Std. } \\
\text { Deviatio } \\
\text { n } \\
\end{array}$ \\
\hline $\begin{array}{l}\text { Perceived } \\
\text { Usefulnes } \\
\text { s (X1) }\end{array}$ & $\begin{array}{l}3 \\
0\end{array}$ & 20 & 48 & 38,83 & 8,603 \\
\hline $\begin{array}{l}\text { Perceived } \\
\text { Ease of } \\
\text { Use (X2) }\end{array}$ & $\begin{array}{l}3 \\
0\end{array}$ & 24 & 48 & 38,50 & 8,581 \\
\hline $\begin{array}{l}\text { Behaviora } \\
1 \text { Intention } \\
\text { to Use (Y) }\end{array}$ & $\begin{array}{l}3 \\
0\end{array}$ & 23 & 48 & 39,20 & 8,495 \\
\hline $\begin{array}{l}\text { Valid N } \\
\text { (listwise) }\end{array}$ & $\begin{array}{l}3 \\
0\end{array}$ & & & & \\
\hline
\end{tabular}

Berdasarkan hasil pengujian statistik deskriptif pada tabel diatas dapat diketahui bahwa jumlah sampel (N) yang dilakukan dalam penelitian ini adalah sebanyak 30 nasabah, Pada tabel 4.14 dapat dilihat bahwa variabel Behavioral Intention to Use (Y) mempunyai nilai ratarata sebesar 39,20 , dengan nilai maksimum sebesar 48 dan nilai minimum 23 dengan nilai standar deviasi sebesar 8,495. Variabel Perceived Usefulness (X1) memiliki nilai rata-rata sebesar 38,83 , dengan nilai maksimum sebesar 48 dan nilai minimum 20 
dengan nilai standar deviasi sebesar 8,603. Variabel Perceived Ease of Use (X2) mempunyai nilai rata-rata sebesar 38,50 , dengan nilai maksimum sebesar 48 dan nilai minimum 23 dengan nilai standar deviasi sebesar 8,8495.

Pengujian normalitas dilakukan dengan analisis Grafik Normal P-P Plot:

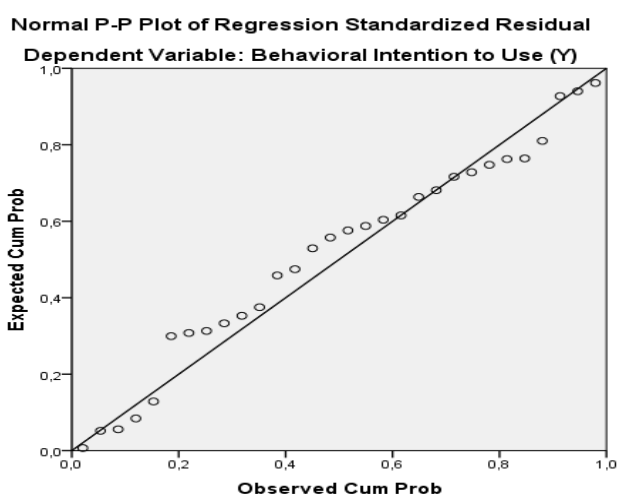

Gambar 2 Hasil Uji Normalitas P-Plot

Dari gambar diatas dapat dilihat bahwa titik-titik menyebar disekitar garis diagonal dan mengikuti arah garis diagonal. Sehingga dapat disimpulkan bahwa data dalam penelitian ini terdistribusi secara normal.

Pengujian normalitas dilakukan dengan uji Kolmogorov-Smirnov(Sugiyono \& Susanto, 2015).

Tabel 12 Hasil Uji Kolmogorov-Smirnov

\begin{tabular}{llr}
\hline & & $\begin{array}{r}\text { Unstandardized } \\
\text { Residual }\end{array}$ \\
\hline $\mathrm{N}$ & & 30 \\
Normal & Mean &, 0000000 \\
Parameters ${ }^{\mathrm{a}, \mathrm{b}}$ & Std. & 4,27663822 \\
& Deviation & \\
Most Extreme & Absolute &, 126 \\
Differences & Positive &, 094 \\
& Negative &,- 126 \\
Test Statistic & &, 126 \\
Asymp. Sig. (2-tailed) &, $200^{c, \mathrm{~d}}$ \\
\hline
\end{tabular}

Berdasarkan tabel diketahui bahwa hasil uji normalitas menunjukkan nilai signifikansi 0,200 yakni berada diatas nilai $\alpha$ atau 0,05, sehingga dapat disimpulkan bahwa data penelitian tersebut adalah berdistribusi normal dan dinyatakan valid.
Uji multikolinearitas adalah uji yang digunakan untuk mengetahui adanya korelasi antara variabel independen, model regresi yang baik adalah tidak adanya korelasi antar variabel independen, dan jika hasil uji adalah ada korelasi antar variabel independen maka terjadi multikolinearitas (Ghozali, 2016).

Tabel 13 Hasil Uji multikolinearitas

\begin{tabular}{llc}
\hline \multirow{1}{*}{ Model } & \multicolumn{2}{c}{$\begin{array}{c}\text { Collinearity } \\
\text { Statistics }\end{array}$} \\
\cline { 2 - 3 } & $\begin{array}{c}\text { Tolera } \\
\text { nce }\end{array}$ & VIF \\
\hline (Constant) & & \\
$\begin{array}{l}\text { Perceived } \\
\text { Usefulness (X1) } \\
\text { Perceived Ease of }\end{array}$ & 0,258 & 3,881 \\
Use (X2) & 0,258 & 3,881 \\
\hline
\end{tabular}

Berdasarkan tabel diatas dapat disimpulkan bahwa variable Perceived Usefulness (X1), dan Perceived Ease of Use (X2), tidak terjadi multikolinieritas karena masing-masing variabel memiliki nilai VIF < 10 dengan nilai Tolerance $>0,1$.

Uji heteroskedastisitas digunakan untuk menguji apakah dalam model regresi, terjadi ketidaksamaan varians dari residual dari suatu pengamatan yang lain:

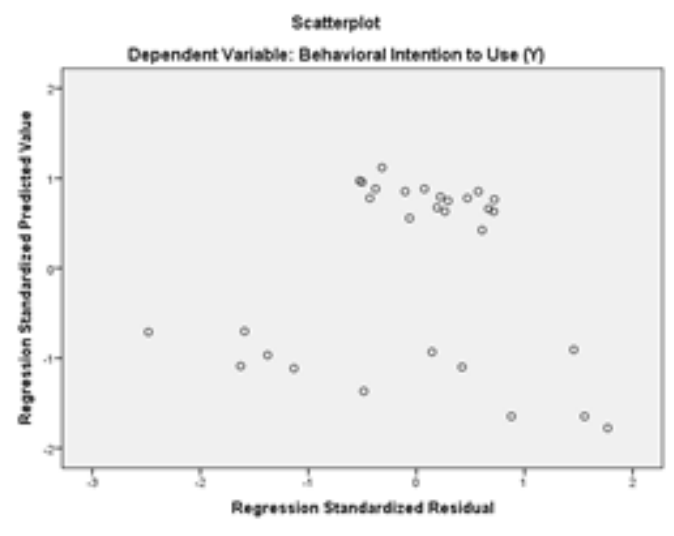

Gambar 2 Hasil Uji Heteroskedastisitas

Dapat diketahui bahwa data tidak membentuk suatu pola tertentu dan titik-titik data tidak hanya mengumpul diatas atau dibawah angka 0 saja melainkan menyebar diatas dan dibawah. Jadi, dapat disimpulkan bahwa tidak ada masalah heteroskedastisitas pada data residual.

Uji Autokorelasi bertujuan untuk mengkaji apakah suatu model regresi linier terdapat korelasi antara kesalahan pengganggu: 
Tabel 14 Hasil Uji Autokorelasi

\begin{tabular}{cccccc}
\hline $\begin{array}{c}\text { Mod } \\
\text { el }\end{array}$ & $\mathbf{R}$ & $\begin{array}{c}\text { Rquar } \\
\text { e }\end{array}$ & $\begin{array}{c}\text { Adjuste } \\
\text { d R } \\
\text { Square }\end{array}$ & $\begin{array}{c}\text { Std. } \\
\text { of the } \\
\text { Estima } \\
\text { te }\end{array}$ & $\begin{array}{c}\text { Durbi } \\
\text { W- } \\
\text { Watso } \\
\mathbf{n}\end{array}$ \\
\hline 1 & $\begin{array}{c}4^{2} \\
4^{\text {a }}\end{array}$ & 0,747 & 0,728 & 4,432 & 1,779 \\
\hline
\end{tabular}

Berdasarkan hasil uji autokorelasi pada tabel 4.13 diperoleh nilai hitung Durbin Watson sebesar 1,779; Sedangkan besarnya DW tabel: dl (batas luar) =1,284; du (batas dalam) = 1,567; 4-du = 2,433; dan 4-dl = 2,716; maka dari perhitungan disimpulkan bahwa DW test tidak terdapat autokolerasi.

Uji Regresi Berganda untuk menguji pengaruh variabel-variabel independen Perceived Usefulness (X1), dan Perceived Ease of Use (X2) terhadap variabel dependen Behavioral Intention to Use (Y):

Tabel 15 Hasil Uji Regresi Berganda

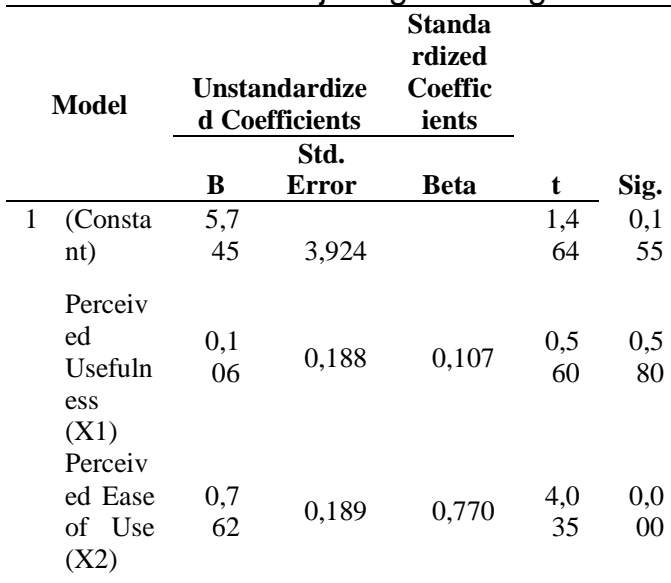

$\mathrm{Y}=5,745+0,106 \mathrm{X} 1+0,762 \mathrm{X} 2+\mathrm{e} 1$

1. Konstanta sebesar 5,745 merupakan perpotongan garis regresi dengan sumbu $Y$ yang menunjukkan variabel terikat Behavioral Intention to Use (Y) sedangkan untuk variabel bebasnya yaitu Perceived Usefulness (X1), dan Perceived Ease of Use (X2), sama dengan nol (0) yang berarti bahwa variabel Behavioral Intention to Use $(Y)$ dapat meningkat sebesar 5,745 tanpa variabel Perceived Usefulness (X1), dan Perceived Ease of Use (X2).

2. Variabel Perceived Usefulness (X1) memiliki koefisien regresi positif. Hal ini menunjukan bahwa bahwa apabila variabel Perceived Usefulness (X1) meningkat sebesar satuan maka variabel Behavioral Intention to Use (Y) juga akan mengalami kenaikan sebesar nilai koefisien regresinya yaitu 0,106 tanpa variabel Perceived Ease of Use (X2).

3. Variabel Perceived Ease of Use (X2) memiliki koefisien regresi positif. Hal ini menunjukan bahwa bahwa apabila variabel Perceived Ease of Use (X2) meningkat sebesar satuan maka variabel Behavioral Intention to Use (Y) juga akan mengalami kenaikan sebesar nilai koefisien regresinya yaitu 0,762 tanpa variabel Perceived Usefulness (X1).

Uji hipotesis dalam penelitian ini menggunakan Signifikansi Parsial (Uji T), Uji Signifikansi Simultan (Uji F), dan Uji Koefisien Determinasi, yaitu sebagai berikut:

Uji t (Parsial) digunakan untuk mengetahui apakah variabel independen secara parsial berpengaruh nyata atau tidak terhadap variabel dependen :

Tabel 16 Hasil Uji t (parsial)

\begin{tabular}{|c|c|c|c|c|c|}
\hline \multirow[b]{2}{*}{ Model } & \multicolumn{2}{|c|}{$\begin{array}{c}\text { Unstandardi } \\
\text { zed } \\
\text { Coefficients }\end{array}$} & $\begin{array}{c}\text { Standard } \\
\text { ized } \\
\text { Coefficie } \\
\text { nts } \\
\end{array}$ & \multirow{2}{*}{$\mathbf{t}$} & \multirow{2}{*}{ Sig. } \\
\hline & B & $\begin{array}{l}\text { Std. } \\
\text { Erro } \\
\mathbf{r}\end{array}$ & Beta & & \\
\hline (Constan & 5,7 & & & 1,4 & \\
\hline t) & 45 & 3,924 & & 64 & 0,155 \\
\hline $\begin{array}{l}\text { Perceive } \\
\mathrm{d} \\
\text { Usefulne } \\
\text { ss (X1) }\end{array}$ & $\begin{array}{r}0,1 \\
06\end{array}$ & 0,188 & 0,107 & $\begin{array}{r}0,5 \\
60\end{array}$ & 0,580 \\
\hline $\begin{array}{l}\text { Perceive } \\
d \text { Ease of } \\
\text { Use (X2) }\end{array}$ & $\begin{array}{r}0,7 \\
62\end{array}$ & 0,189 & 0,770 & $\begin{array}{r}4,0 \\
35\end{array}$ & 0,000 \\
\hline
\end{tabular}

Dari tabel diatas menunjukkan bahwa hasil perhitungan analisis regresi linear berganda diperoleh nilai sebagai berikut:

1. Perceived Usefulness (X1) memiliki nilai thitung sebesar 0,560 sedangkan ttabel sebesar 1,697 yang artinya bahwa thitung lebih besar dari ttabel $(0,560<1,697)$, dengan signifikasi sebesar 0,580 atau lebih besar dari nilai probabilitas $(0,580>0,05)$. Hal ini menunjukkan bahwa $\mathrm{H} 1$ ditolak, artinya terdapat tidak berpengaruh dan tidak signifikan antara variabel Perceived Usefulness (X1) terhadap variabel Behavioral Intention to Use $(Y)$.

2. Perceived Ease of Use (X2) memiliki nilai thitung sebesar 4,035 sedangkan 
ttabel sebesar 1,697 yang artinya bahwa thitung lebih besar dari ttabel $(4,035>1,697)$, dengan signifikasi sebesar 0,000 atau lebih kecil dari nilai probabilitas $(0,00<0,05) \quad \mathrm{Hal}$ ini menunjukkan bahwa H2 diterima, artinya terdapat pengaruh dan signifikan antara variabel Perceived Ease of Use (X2) terhadap variabel Behavioral Intention to Use ( $\mathrm{Y})$.

Uji statistik $f$ (simultan) pada dasarnya menunjukkan apakah semua variabel independen yang dimasukkan dalam model mempunyai pengaruh secara bersamasama terhadap variabel terikat (Hartati et al., 2020)

Tabel 17 Hasil Uji f (simultan)

\begin{tabular}{lrrrrr}
\hline Model & $\begin{array}{c}\text { Sum of } \\
\text { Square } \\
\text { s }\end{array}$ & df & $\begin{array}{c}\text { Mean } \\
\text { Square }\end{array}$ & F & Sig. \\
\hline $\begin{array}{l}\text { Regressi } \\
\text { on }\end{array}$ & 1562,40 & 2 & 781,200 & 39, &, 00 \\
Residual & 530,399 & 27 & 19,644 & & \\
Total & 2092,80 & 29 & & & \\
& 0 & & & & \\
\hline
\end{tabular}

Berdasarkan tabel di atas nilai Fhitung sebesar 39,767 sedangkan nilai Ftabel sebesar 2,92, dengan tingkat signifikasi sebesar 0,00 atau lebih kecil dari 0,05 , artinya secara bersama-sama terdapat pengaruh positif dan signifikan antara variabel Perceived Usefulness (X1), dan Perceived Ease of Use (X2), terhadap variabel Behavioral Intention to Use $(\mathrm{Y})$.

Pengujian koefisien determinasi dilakukan untuk mengukur seberapa jauh kemampuan model regresi dalam menerangkan variabel dependen:

Tabel 18 Hasil Koefisien

\begin{tabular}{lcccc}
\hline Model & $\mathbf{R}$ & $\begin{array}{c}\mathbf{R} \\
\text { Square }\end{array}$ & $\begin{array}{c}\text { Adjusted } \\
\text { R Square }\end{array}$ & $\begin{array}{c}\text { Std. } \\
\text { Error of } \\
\text { the } \\
\text { Estimate }\end{array}$ \\
\hline 1 &, $864^{\mathrm{a}}$ & 0,747 & 0,728 & 4,432 \\
\hline
\end{tabular}

hasil koefisien determinan atau besarnya nilai koefisien determinasi sebesar 0,864 yang berarti variabel Behavioral Intention to Use $(Y)$ dapat dijelaskan oleh variabel Perceived Usefulness (X1), dan Perceived Ease of Use (X2) sebesar 86,4\% sedangkan sisanya $13,6 \%$ dijelaskan oleh variabel- variabel lain yang tidak diteliti dalam penelitian ini.

\section{Kesimpulan}

Hasil dari penelitian ini dapat disimpulkan bahwa variabel Perceived Usefulness tidak berpengaruh dan tidak signifikan terhadap Behavioral Intention to Use di PT. Pegadaian (Persero), Perceived Ease of Use berpengaruh dan signifikan terhadap kinerja karyawan di Behavioral Intention to Use di PT. Pegadaian (Persero) dan Perceived Ease of Use serta Perceived Ease of Use berpengaruh dan signifikan terhadap kinerja karyawan di Behavioral Intention to Use di PT. Pegadaian (Persero).

\section{Referensi}

Ahmad, A. (2013). Perkembangan Media Online Dan Fenomena Disinformasi ( Analisis Pada Sejumlah Situs Islam ) Online Media Development And Phenomenon Of Disinformation ( Analysis Of Islamic Sites ). Jurnal Pekommas, 16(3), 177-186.

Atchariyachanvanich, K., Okada, H., \& Uesugi, S. (2011). The Technology Acceptance Model. InterOrganizational Information Systems And Business Management, 234250. Https://Doi.Org/10.4018/978-160960-768-5.Ch015

Ghozali, I. (2016). Aplikasi Analisis Multivariete Dengan Program IBM SPSS 23 (Edisi 8). Cetakan Ke VIII. Badan Penerbit Universitas Diponegoro.

Ghozali, I., \& Ratmono, D. (2017). Analisis Multivariat Dan Ekonometrika Dengan Eviews 10. Badan Penerbit Universitas Diponegoro.

Hartati, S., Choiruddin, Winarko, H., \& Martini, R. (2020). Akuntabilitas Publik Dari Aspek Pembukuan, Inventarisasi, Dan Pelaporan Aset Tetap. 9(1).

Hartatik, S. R., \& Budihartanti, C. (2020). Analisis Kepuasan Pengguna Terhadap Penerapan Aplikasi GoJek Dengan Menggunakan Metode Tam ( Technology Acceptance Model ). 7(1).

Jahangir, N., \& Begum, N. (2008). The Role Of Perceived Usefulness, Perceived Ease Of Use, Security And Privacy, And Customer Attitude To Engender Customer Adaptation 
In The Context Of Electronic Banking. 2(1), 32-40.

Kasmir. (2015). Bank Dan Lembaga Keuangan Lainnya. PT. Raja Grafindo Persada.

Priyatno, D. (2014). SPSS 22 Pengolahan Data Terpraktis. CV. Andi Offset.

Sholikhah, A. (2016). Statistik Deskriptif Dalam Penelitian Kualitatif. KOMUNIKA: Jurnal Dakwah Dan Komunikasi, $\quad 10(2), \quad 342-362$. Https://Doi.Org/10.24090/Komunika .V10i2.953

Subagio, H., \& Jessica, J. (2020). Pengaruh Perceived Usefulness, Perceived Ease Of Use, Subjective Nor M, Da N C Ust Omer E Xpe Rie N Ce Terh Ad Ap I N Tention T O Use Mytelkomsel (Studi Kasus Pada Mahasiswa Universitas Kristen Petra Surabaya). Https://Www.Google.Com/Url?Sa= $T \& R c t=J \& Q=\& E s r c=S \&$ Source $=W e$ $\mathrm{b} \& C \mathrm{~d}=\& C a d=R j a \& U a c t=8 \& V e d=2 a$ hukewiwpmrw96jyahu5lesfhxyoahc qfnoecawqaq\&Url=Http\%3A\%2F\%2 Fpublication.Petra.Ac.Id\%2Findex. Php\%2Fmanajemen-

Pemasaran\%2Farticle\%2Fdownloa d\%2F10193\%2F9123\&Usg=Aovva w3qokenrruzx7qbhcnxy7jg

Sugiyono. (2014). Metode Penelitian Pendidikan Pendekatan Kuantitatif, Kualitatif, Dan R\&D. Alfabeta.

Sugiyono. (2015). Metod Penelitian Kombinasi (Mix Methods). Alfabeta.

Sugiyono, \& Susanto, A. (2015). Cara Mudah Belajar SPSS \& Lisrel. CV. Alfabeta:

Wulandari, I. R. (2020). Analysis Of Behavior Using E-Money With A TAM Approach ( Technology Acceptance Model ). 10(01), 24-32. 